The International Journal of Engineering and Science (IJES)

|| Volume || 6 || Issue || 6 || Pages || PP 69-73 || 2017 ||

ISSN (e): $2319-1813$ ISSN (p): $2319-1805$

THE IJES

\title{
Studio of District Upgrading Project in Amman - Jordan Case Study - East District Wahdat
}

\author{
Dr. Architect Bassam Abu Awwad \\ Jerash University - College of Engineering -Facultyof Architectural
}

\begin{abstract}
-
The research aims to put in evidence a complex issue at national and international level as that of the housing situation of wellness investigating a case study as that of East Wahdat,in Amman in Jordan from the design point of view welfare, the training model of this district then the causes of abusive settlements and their genetic code development, also studying system of life within the district as the level of study cultural and the economic situation of the inhabitants, finally the model of intervention and which was carried out by local public bodies such as $H C, U D D$, following an innovative strategies in that area which is to the participation of the inhabitants in the decision of intervention by upgrading and car construction. This Type Of intervention in districtESTWahdat has said many national interest and international and was chosen as the best project for upgrading and rehabilitation of degraded areas in Istanbul in 95, to the speed of intervention, the cost and duration of the work. We have analyzed the problem of the district after 20 years of intervention and as this district still suffers of overcrowding which was not provided for in the first intervention, and infrastructure problems motivated by the abandonment of the government, and we have highlighted some recommendation to preserve this district.
\end{abstract}

Keywords: Upgrading, degradation, requalification, development, Housing Corporation HC, Urban Development Department UDD.

Date of Submission: 04 April 2017

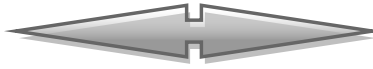

Date of Accepted: 24 April 2017

\section{Introduction}

This is a neighborhood located south-east of Amman, close to the largest Palestinian refugee camp, is alWahdat. It covers an area of 9.1 hectares, counts 50.300 inhabitants and 524 buildings abusive (90\%) and 58 shop. The buildings are all made with material not stable as zinc and sheets, have a maximum elevation of two floors; the height of each plan does not exceed two meters and all these houses are free services and ventilation. The trace of streets and alleys is irregular and spontaneous and not connects all the houses in the neighborhood. The choice has fallen on this district because it satisfies all the requirements mentioned above. The policy applied in this district was to give the possibility to the inhabitants of purchase - accessing loans - soil on which rises the abusive House (by then reconstruct according to the regulations in force) and use the proceeds of the sale of the land to build all the infrastructure networks (Housing Corporation HC, Urban Development Department UDD), (AL ZOUBI Ahmad, the experience of the UDD in Jordan, residential studio 1991-1992, Amman).

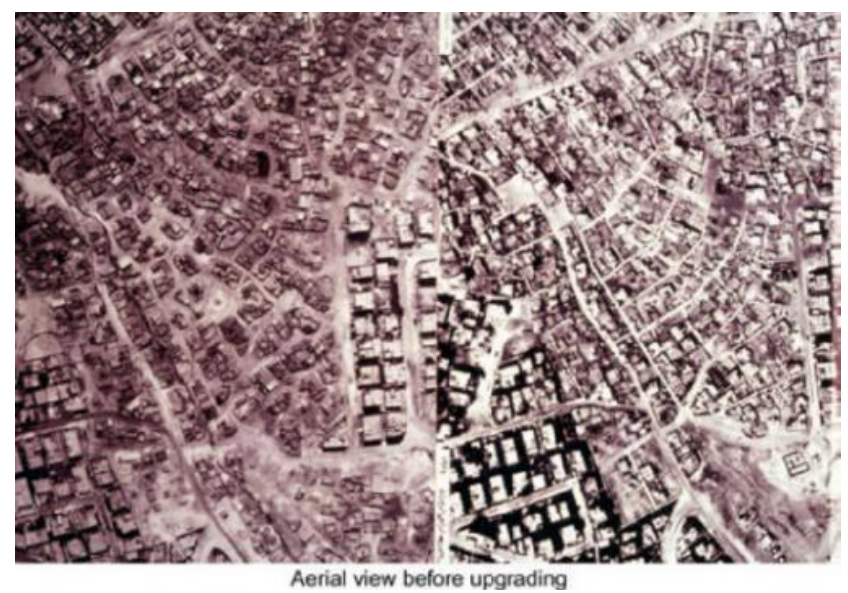

Figure .1- East District Wahdat. 


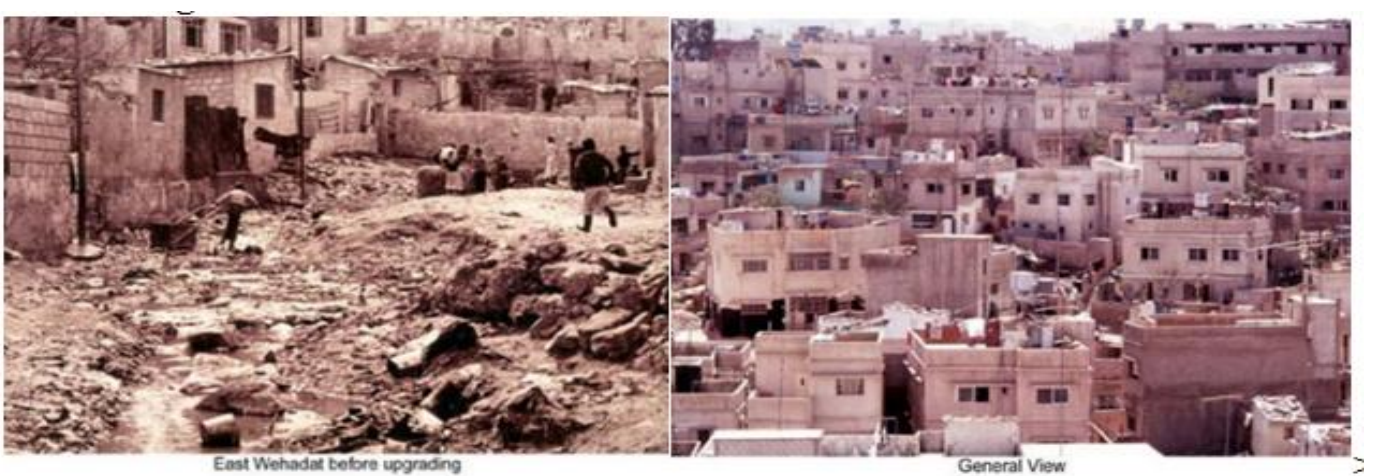

Figure 2.A- B-East District Wahdatgeneral view before upgrading: it is evident that there is considerable degradation from the abandonment of the district by government bodies.

\section{Objectives To Be Achieved For Upgrading East District Wahdat}

1. Give the inhabitants a certainty housing, thanks to the possibility to legitimize the possession of houses built illegally.

Provide the district of all the necessary services such as water, electricity and sewage networks. 2

3. Reduce the environmental pollution caused by the abandonment of waste in the free areas of the district

Reduce overcrowding of homes through the transfer of some families in other areas.4.

Redraw the territorial planning in a regular manner, by dividing the district in several small batches from 100 to 200 meter quadrat, in accordance with local regulations.

5. Provide the district of all infrastructures: roads, gardens, parking for private cars

Build commercial centers managed by the resident themselves..6

7. Build professional schools in order to tackle the problems of unemployment within the district, thanks to the aid of private investors

8. Improve the cultural level of the inhabitants fighting illiteracy, strongly present especially among women

9. Involve inhabitants in interventions of improvement, creating monitoring committees work in progress.

The jobs in the district have lasted two years, from 1982 to 1984. Furthermore, it was the first project of upgrading made in Jordan, with minimum costs (3.15 million JD), entirely covered with beneficiaries. (Housing Corporation $\mathrm{HC}$ )

\section{The Most Significant Results}

1. Improvement of the housing situation, with the creation of houses adapted to respond to the concept of a better quality of life.

2. Preservation of local traditions as well as originated by the inhabitants ex abusive within the district.

3. Improvement of the hygienic situation and environment, with important effects: the infant mortality rate has risen from $6.8 \%$ in 1981 before upgrading to $5.5 \%$.

4. Grew the gains of investors, thanks to the creation of professional schools and the construction of social centers.

5. Improvement of the social and cultural situation, especially for women, with targeted interventions to combat illiteracy.

6. Reduction of unemployment, thanks to the formation of cooperatives managed by the same inhabitants.

The project of the East DistrictWahdat was chosen as the best project for upgrading in July 199 in Istanbul, at the International Congress of the United Nations on the house. (Cooperationhuosing building text in Arabic, Amman 1990)..

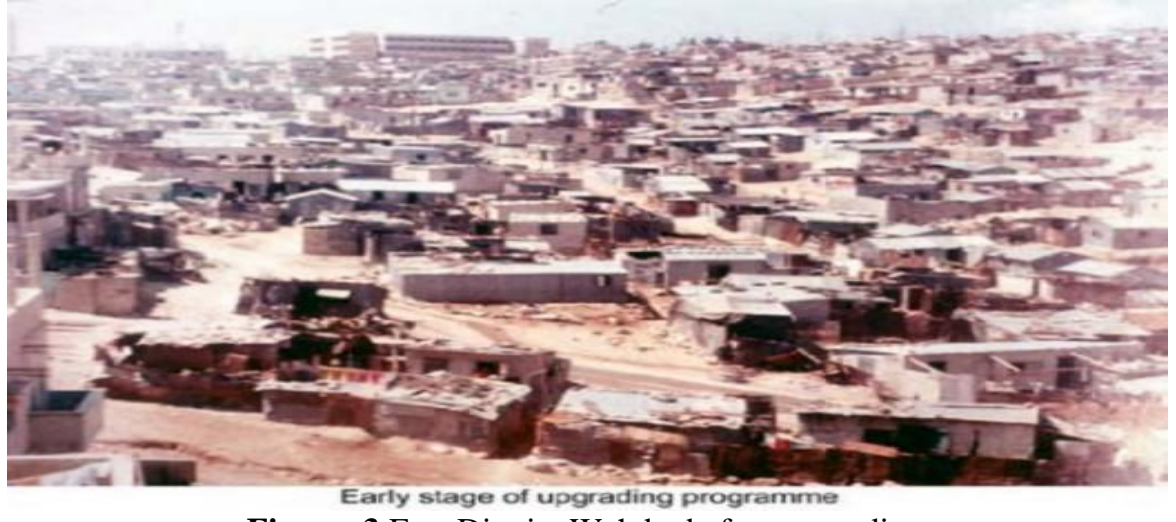

Figure .3 East District Wahdat before upgrading 


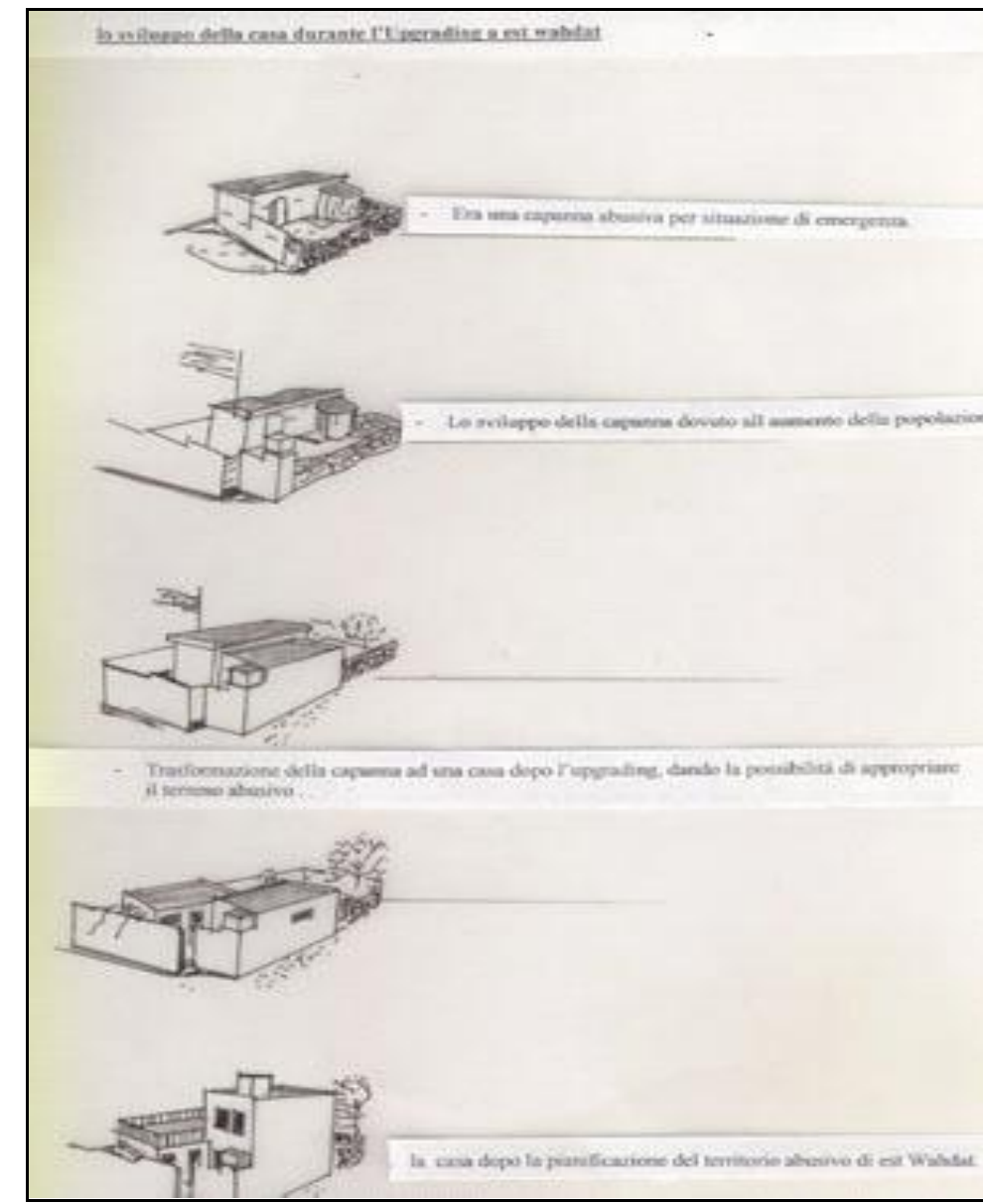

Figure4.Models of development of the houses in East DistrictWahdat home brewing (local)

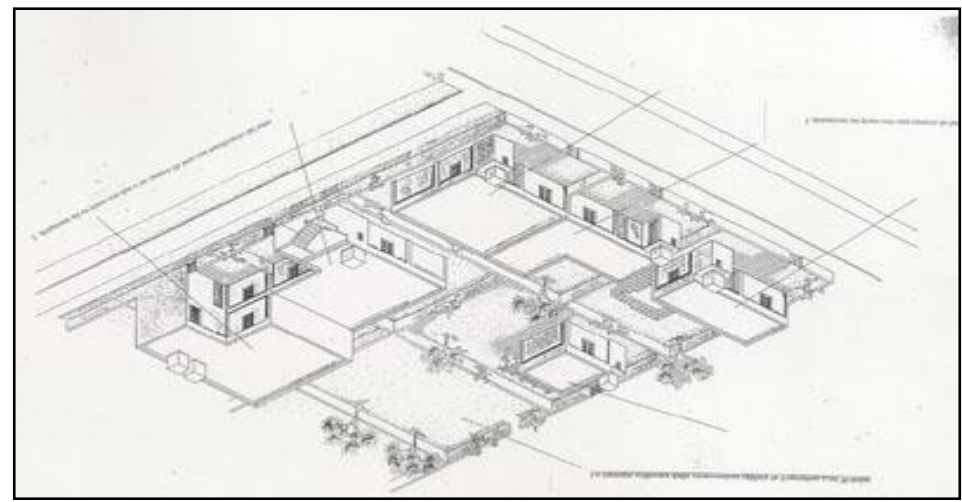

Figure .5.The models of living in the upgrading
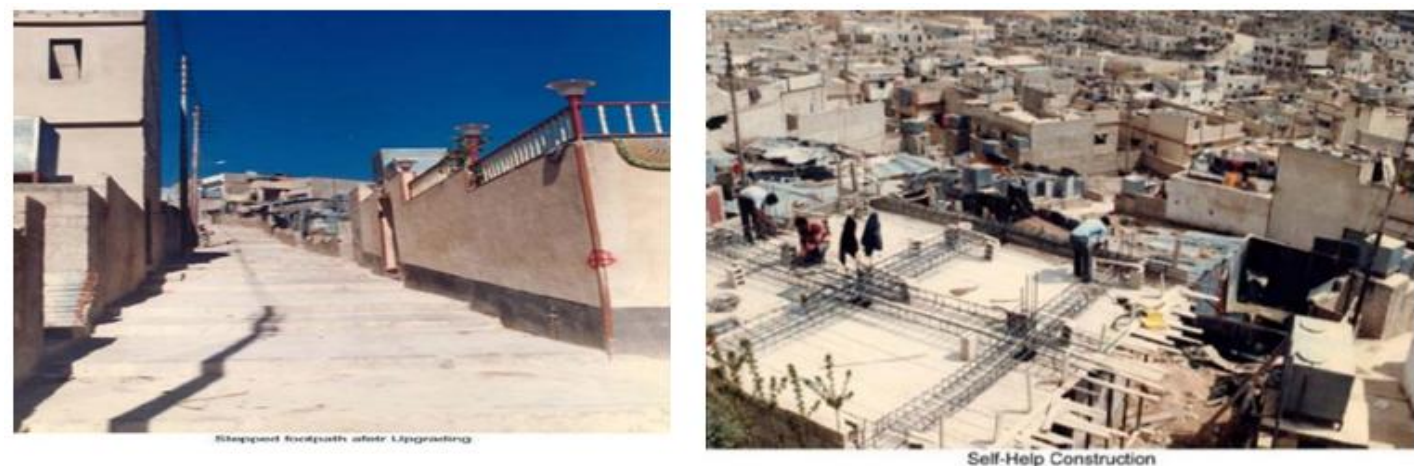

Figure.6A-B.The models of living in the upgrading proposed by public entities House Corporations (H.C., UDD) three type of auto constructions 


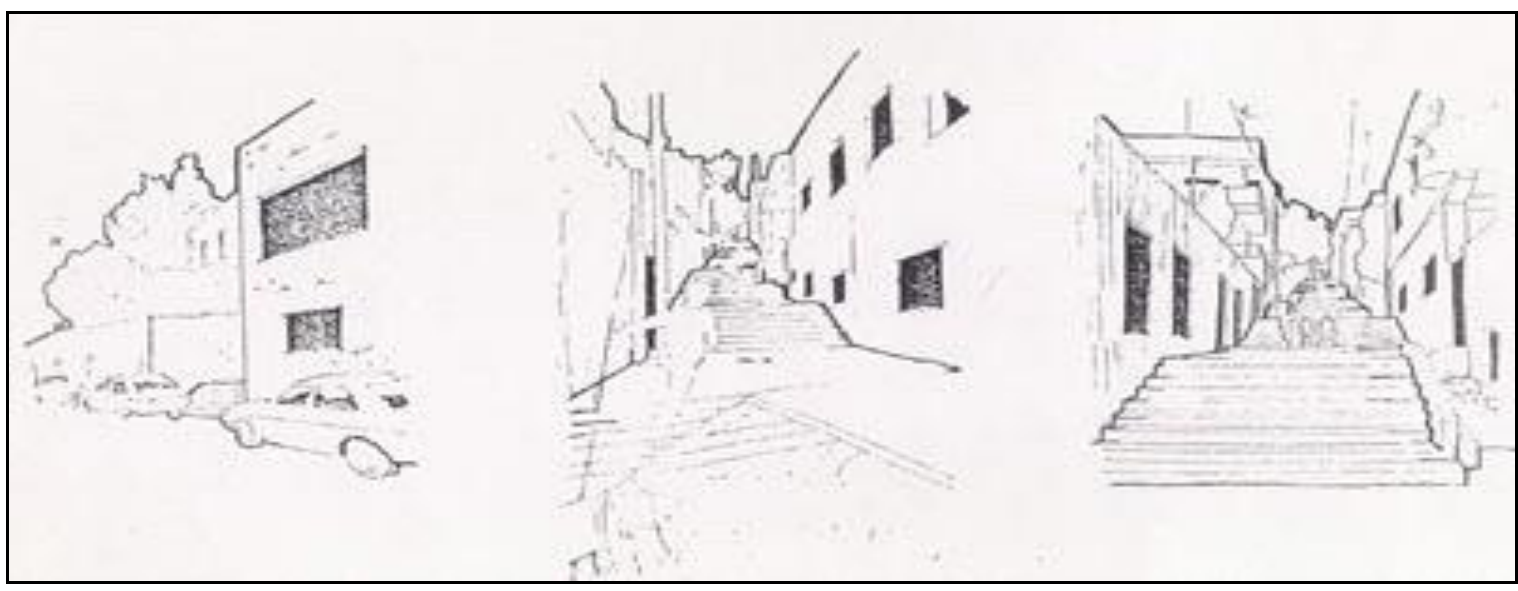

Figure.8 The models of living in the upgrading proposed by public entities

\section{Conclusion.Parameters Of Evaluations-Amman}

Table.1 Turn Tools before management \& upgrading of degraded areas case study East district Wahdat

\begin{tabular}{|c|c|c|}
\hline Criterion & Quality Indicator & Tools of Quality \\
\hline $\begin{array}{l}\text { Information of citizenship. } \\
\text { Management participate of Different } \\
\text { communities. } \\
\text { Management participate resources. } \\
\text { Instructions and professionalism } \\
\text { Involve citizenship. } \\
\text { Resource utilization present. } \\
\text { Involving international bodies and } \\
\text { private. } \\
\text { Share of the criterion of the } \\
\text { neighborhoods like Preservation of } \\
\text { houses from overcrowding. } \\
\text { Criterion of adjustment and positioning } \\
\text { of the territory. }\end{array}$ & $\begin{array}{l}\text { Information Action. } \\
\text { ActionParticipation } \\
\text { management.. } \\
\text { Tools for instructions. } \\
\text { Action of engagement. } \\
\text { Action of resources. } \\
\text { Action of involvement. } \\
\text { Instrument of share of criterion. } \\
\text { Indicator for the overcrowding. } \\
\text { Indicator for the territory. }\end{array}$ & $\begin{array}{l}\text { The training of users are limited, and formal. } \\
\text { There are limited public participation. } \\
\text { There are limited action at the level of consult to } \\
\text { manage the resources of the district. } \\
\text { The level of instruction and training is limited. } \\
\text { Are limited actions organic Involvement for } \\
\text { systematic and periodic with only effect of } \\
\text { advertising promises? } \\
\text { 1. Models of the constant training of the inhabitants. } \\
\text { 2.reassessing the resources present . } \\
\text { Models of involvement. } \\
\text { 3. There are market share well defined the type of } \\
\text { appropriate accommodation for users to limited } \\
\text { income. } \\
\text { There are no indicator. } \\
\text { There are no criterion of evaluation of the territory. }\end{array}$ \\
\hline
\end{tabular}

\begin{tabular}{|c|c|}
\hline Problems & Objective \\
\hline $\begin{array}{l}\text { Lack of advertising for adequate information. } \\
\text { Absence of information program } \\
\text { Strong and steady presence of unauthorized. } \\
\text { Absence of confidence on the part of users in public } \\
\text { bodies } \\
\text { Abandonment of human resources. } \\
\text { Lack of adequate policies to manage resources. } \\
\text { Lack of training programs and instructions to enhance } \\
\text { their human resources. } \\
\text { The serious economic problems have forced the } \\
\text { inhabitants away from schools. } \\
\text { Lack of seriousness of bodies responsible for improving } \\
\text { the quality of life. } \\
\text { The absence of models of redevelopment of the } \\
\text { neighborhood suitable. } \\
\text { Are there lack of collaboration with the inhabitants in } \\
\text { the action of redevelopment of District? } \\
\text { The development of the district away of mushroom of } \\
\text { brick. } \\
2 . \text { The strongly rising unemployment internal } \\
\text { 1.lack of interest on the part of public bodies . } \\
\text { Absence of plans to advertise to improve the district. } \\
\text { The random development district of mushroom of brick } \\
\text { Lack of application of the rules of the master plan for } \\
\text { the degraded areas the abandonment by the bodies } \\
\text { concerned } \\
\text { Theovercrowding } 5 \text { person/room, lack of an adequate } \\
\text { lack a proper schedules for these areas, lack of a plan } \\
\text { for the expropriation of the territory in favor of the } \\
\text { construction of adjust. The strong overcrowding } 5 \\
\text { person/room }\end{array}$ & $\begin{array}{l}\text { Create instruments informative constants for directing the user to the } \\
\text { problems of the district. } \\
\text { Encourage the collective work and forms of partnership } \\
\text { Promotes the subsidiarity. } \\
\text { The intention to create schools of formations for the cultural level of the } \\
\text { inhabitants. } \\
\text { Encourage a full knowledge of the problems of the district. } \\
\text { Creations from a joint committee (inhabitants, public institution) for } \\
\text { action to improve. } \\
\text { Improve the instruments present, introducing more effective instruments } \\
\text { for the use of resources present how to create the collective cooperatives } \\
\text { to combat unemployment, degradation of the environment. } \\
\text { Publicity the district at private entities and international. } \\
\text { The idea of introducing to plans to lock the unauthorized building. } \\
\text { Make a plan detailed regulatory framework that provides for the } \\
\text { obligation of the expropriation to promote the regular accommodation. } \\
\text { Streamline the quarters by according with the inhabitants. } \\
\text { Introducing means of adjustment of the territory to reach the condition } \\
\text { of well-being. }\end{array}$ \\
\hline
\end{tabular}


Are raped the free spaces by abusivesteps are not adequate is very narrowSteep slope of the territory Difficult.

\section{Recommendation}

General problems related to upgrading all in all the work of improvement is a work limited and incomplete because of the following factors.In the case of an intervention of improvement of the district and not of retraining real, is often limited and does not solve all the problems of the district, in particular the overcrowding, Is a job that does not provide for the development of the district in the years, but it concerns the current problems; therefore every ten years there is a need for a new program for improvement.. The duration of the intervention often exceeds the prescribed time, thus creating various problems linked to the chaos caused and the consequent inconvenience for the inhabitants. Does not show any economic improvement, unemployment but still too high levels. Public and private bodies that were interested in upgrading have abandoned their interest. Culture of unauthorized still exists but in a more limited due to the economic situation of the inhabitants.

\section{References}

[1] Cooperationhuosing building text in Arabic, Amman 1990

[2] Residential studies and the experience of the private sector", 1991 - 1992, University of Jordan Amman, Faculty of higher studies of architectureMinistry of Public Works - 1988.

[3] The urban structure between legislation and control, study on the city of Amman "report presented to the biennial conference of architecture in Amman titled "The ruler organizational and their relations with urban planning in Jordan 1993.

[4] AL ZOUBI Ahmad, the experience of the UDD in Jordan, residential studio 1991-1992, Amman.

[5] The United Nations Relief and Work Agency, Agency of the United Nations was created in 1948 to tackle the problem of the Palestinian refugees who fled or hunted by Israel after the first Arab-Israeli ware.

[6] Greater Amman Comprehensive Development Plan, vol. 4, Municipality of Amman, 1987; H.C. \& UDD, strategies and techniques of intervenor retraining, Amman, 1993, pp. 13-34; HAYMOUR R. TAHOUN, S., Amman: prospects for recovery of degraded areas and refugee camps, thesis. 